\title{
The Improvement of the spatial structure and quality of rural communication system in loess upland watershed
}

\author{
RAFAŁ WAWER ${ }^{1,3}$, EUGENIUSZ NOWOCIEN' ${ }^{1}$, BUGUSŁAW PODOLSKI ${ }^{1}$, \\ SZYMON SZEWRAŃSKI ${ }^{2}$, ROMUALD ŻMUDA ${ }^{2}$ \\ ${ }^{1}$ Institute of Soil Science and Plant Cultivation - State Research Institute \\ ${ }^{2}$ Agricultural University of Wroclaw \\ ${ }^{3}$ Spatial Applications Division, Katholieke Universiteit Leuven
}

\begin{abstract}
The Improvement of the spatial structure and quality of rural communication system in loess upland watershed. In strongly eroded terrains, a considerable part of agricultural roads are transformed into ravines, as a result of their inappropriate location in the terrain relief. Hence the arrangement and hardening of rural roads remains an essential component of formation of arable areas on eroded terrains. Correct derivation of the roads, which need the protective measures or even re-projecting improves the state of the road network in economically effective way, as it allocates the available resources to the most threatened areas. The article presents a study on the actual state of the net of rural roads on loess upland terrain of Mielnica watershed. The analysis, performed on digital spatial data within GIS software, revealed considerable needs for improvements of rural roads on investigated area. Basing on the results, the map of improvement measures has been developed, presenting a spatial base for a decision support system for future land improvements and allocation of economical resources for the management of rural surface communication network in rural-environmental plans.
\end{abstract}

Key words: soil erosion, loess watershed, rural communication system, improvement measures.

\section{INTRODUCTION}

The arrangement and hardening of rural roads is an essential component of formation of arable areas on eroded terrains
$[5,7,8,11,12,16]$. Correctly traced and hardened roads facilitate not only husbandry, but also fulfill the role of anti-erosion meliorations, distracting superficial flows or discharging the excess of waters. The literature recommends locating the rural roads transversely to the slope of a terrain $[10,11,12]$. This is correct from the anti-erosion point of view, although such roads are less functional than those led obliquely to the slope. In practice, however, the diagonal roads, slope-along roads and roads on bottoms of valleculaes are the most strongly eroded ones, since the intensity of superficial flow is much higher than on adjacent slopes, reaching intensities high enough to cause rilling and in consequence development of various forms of gullies $[9,12]$. The dynamics of the deepening of rural roads on loess terrains reach $4.5 \mathrm{~cm}$ to $9.0 \mathrm{~cm}$ per annum [9]. The agricultural roads remain the main source of debris reaching river valleys $[1,13]$.

The article presents a study on the actual state of the net of rural roads on loess upland terrain of Mielnica watershed. The analysis, performed on digital 
spatial data within GIS software, revealed considerable needs for improvements into rural roads on investigated area. The results present a spatial base for a decision support system for future land improvements and allocation of economical resources for the management of rural surface communication network in rural-environmental plans.

\section{MATERIALS AND METHODS}

\section{Area of investigations}

The investigations were conducted in years 2003-2005 on an area of the rural upland watershed of the Mielnica stream, lying on Wzgórza Trzebnickie, located about $50 \mathrm{~km}$ NNE from Wroclaw in dolnoślaskie district. The area of the watershed equaling to $6.7 \mathrm{~km}^{2}$ is characterized with relatively homogenous silty and loess soil cover and rich terrain's relief. The natural conditions, especially long, steep slopes favor various form of water erosion; rills, gullies. Existing net of agricultural roads (ca $20 \mathrm{~km}$ ) undergo intensive deepening and degradation in the seasons of snow melting and summer storms.

\section{Source of data}

The basis of performed spatial analyses was the digital model of Mielnica watershed, consisting of different groups of spatial layers created through digitalization and digital processing of analog data [14], such as:

- topographical map in scale of 1:10 000;

- soil-agricultural map in scale of 1:5000;

- aerial ortho-photo map from a target run in May 1996, with scale 1:26 000 and digital resolution of $1 \mathrm{~m}$;
The analog data were transformed into a digital form through:

- Digitalisation "on screen" of the network of public and rural roads from topographical map in scale 1:10 000 within the ArcView (C) 3.1 programme;

- "On- screen" digitalization of soil polygons from soil-agricultural map.

- "On- screen" digitalisation of contour lines

- Interpolation of contour lines to DEM with spatial resolution of $10 \mathrm{~m}$, with use of the TOPOGRID method [3].

\section{Method of investigations}

The study bases on two main indicators, which describe the state of the existing network of rural roads: IARRR [15] indicator and UHRR [14] indicator.

The IARRR [15] method of tracing agricultural roads in a terrain relief bases on comparison between azimuths of internodal road sections and terrain aspect. The aspect is understood as the steepest downward direction from each cell to its neighbors $[2,15]$. The values of the aspect grid represent the compass direction of the aspect; 0 is true north, 90 degree aspect is east, and so forth. For purposes of the analysis of arrangement of agricultural roads in the relief, a semiautomatic digital implementation was worked out and adopted to the ArcView GIS 3.2 system. Vectorized agricultural roads with the ground surface were divided initially into sections through overlay cutting in points of intersection with elevation contour lines, between which the terrain slope is assumed to be constant. Next, the azimuth [2] has been calculated for every internodal section of the agricultural road. The road sections 
have then been covered with an aspect grid layer, assigning values of the terrain aspect to the road database. Values of azimuths of agricultural roads and terrain aspect were transformed to range from 90 to 90 degrees, with 0 for the $\mathrm{N}$ direction. In the next step, the difference between the road azimuths and terrain aspect in the central point of individual sections of roads was calculated. The resulting

TABLE 1. Decision rule for estimating UHRR indicator [14]

\begin{tabular}{|c|c|c|}
\hline $\begin{array}{c}\text { Longitudal } \\
\text { inclination } \\
\text { of road's } \\
\text { surface }\end{array}$ & Kinds of soils underlying road's surface & $\begin{array}{l}\text { UHRR } \\
\text { indicator }\end{array}$ \\
\hline$\%$ & & \\
\hline \multirow{4}{*}{$<4$} & $\begin{array}{l}\text { Non-expandable soils: sandy gravel, loose sand, calcarous soils, crystal rock, } \\
\text { aqueous rock,solid rock, rocky debris. }\end{array}$ & 4 \\
\hline & $\begin{array}{l}\text { Questionable soils: silty loose Sand, weak loamy Sand, silty weak loamy } \\
\text { sand, light loamy sand, silty light loamy sand, loamy gravel. }\end{array}$ & 4 \\
\hline & $\begin{array}{l}\text { Less expandable soils: sandy loam, silty sandy loam, light loam, light silty loam, } \\
\text { middle loam, loess soils, clayey loess soils, silty clay, clay, all rendzinas. }\end{array}$ & 4 \\
\hline & $\begin{array}{l}\text { Very expandable soils: strong loamy sand, strong silty loamy sand, silty middle } \\
\text { loam, heavy loam, heavy silty loam, sandy silt, oridinary silt, loamy silt, clayey } \\
\text { silt, all muds. }\end{array}$ & 4 \\
\hline \multirow{4}{*}{$4-8$} & $\begin{array}{l}\text { Non-expandable soils: sandy gravel, loose sand, calcarous soils, crystal rock, } \\
\text { aqueous rock, solid rock, rocky debris. }\end{array}$ & 4 \\
\hline & $\begin{array}{l}\text { Questionable soils: silty loose Sand, weak loamy Sand, silty weak loamy } \\
\text { sand, light loamy sand, silty light loamy sand, loamy gravel. }\end{array}$ & 3 \\
\hline & $\begin{array}{l}\text { Less expandable soils: sandy loam, silty sandy loam, light loam, light silty loam, } \\
\text { middle loam, loess soils, clayey loess soils, silty clay, clay, all rendzinas. }\end{array}$ & 2 \\
\hline & $\begin{array}{l}\text { Very expandable soils: strong loamy sand, strong silty loamy sand, silty middle } \\
\text { loam, heavy loam, heavy silty loam, sandy silt, oridinary silt, loamy silt, clayey } \\
\text { silt, all muds. }\end{array}$ & 1 \\
\hline \multirow{4}{*}{$8-12$} & $\begin{array}{l}\text { Non-expandable soils: sandy gravel, loose sand, calcarous soils, crystal rock, } \\
\text { aqueous rock, solid rock, rocky debris. }\end{array}$ & 3 \\
\hline & $\begin{array}{l}\text { Questionable soils: silty loose Sand, weak loamy Sand, silty weak loamy } \\
\text { sand, light loamy sand, silty light loamy sand, loamy gravel. }\end{array}$ & 2 \\
\hline & $\begin{array}{l}\text { Less expandable soils: sandy loam, silty sandy loam, light loam, light silty loam, } \\
\text { middle loam, loess soils, clayey loess soils, silty clay, clay, all rendzinas. }\end{array}$ & 1 \\
\hline & $\begin{array}{l}\text { Very expandable soils: strong loamy sand, strong silty loamy sand, silty mid- } \\
\text { dle loam, heavy loam, heavy silty loam, sandy silt, oridinary silt, loamy silt, } \\
\text { clayey silt, all muds. }\end{array}$ & 1 \\
\hline \multirow{4}{*}{$>12$} & $\begin{array}{l}\text { Non-expandable soils: sandy gravel, loose sand, calcarous soils, crystal rock, } \\
\text { aqueous rock, solid rock, rocky debris. }\end{array}$ & 1 \\
\hline & $\begin{array}{l}\text { Questionable soils: silty loose Sand, weak loamy Sand, silty weak loamy } \\
\text { sand, light loamy sand, silty light loamy sand, loamy gravel. }\end{array}$ & 1 \\
\hline & $\begin{array}{l}\text { Less expandable soils: sandy loam, silty sandy loam, light loam, light silty loam, } \\
\text { middle loam, loess soils, clayey loess soils, silty clay, clay, all rendzinas. }\end{array}$ & 1 \\
\hline & $\begin{array}{l}\text { Very expandable soils: strong loamy sand, strong silty loamy sand, silty middle } \\
\text { loam, heavy loam, heavy silty loam, sandy silt, oridinary silt, loamy silt, clayey } \\
\text { silt, all muds. }\end{array}$ & 1 \\
\hline
\end{tabular}


difference represents a flat horizontal angle between a segment of the road and terrain aspect, i.e. the line with the highest slope, which can be considered as the line lying ideally with the slope. Through transposition it is possible to import this value to an angle between the road section and line ideally perpendicular to slope, representing simultaneously the zero slope. The resulting angle represents the Indicator of Arrangement of Rural Roads in Relief (IARRR) [15].

The UHRR [14] method derives classes of the Urgency of Hardening Rural Roads and strengthening their draining infrastructure. Considering longitudal inclinations of road's surface and the class of soil expandability, derived from the soil kind, the method distinguishes four grades of the urgency of hardening roads' surface and strengthening superficial draining devices:

- grade 1: very urgent,

- grade 2: urgent,

- grade 3: moderately urgent,

- grade 4: advisable locally.

The complete decision rule is shown in Table 1 [14].

The spatial layer containing the road network has been cut with elevation contours, derived form $10 \mathrm{~m}$ resolution DEM. The herewith created road sections have been then cut and overlaid with the layer of soil expandability, derived form soil-agricultural map. Then the longitudal slopes have been calculated with help of ArcView GIS extension "Surface Tool for Points, Polylines and Polygons" [4]. Using database operations the decision rule of estimating UHRR has been executed, revealing the final map of the urgency of road hardening and strengthening of roads' draining devices derived into 4 classes.

\section{RESULTS}

\section{IARRR indicator}

The results show unfavorable structure of rural roads in terrain's relief (Tab. 2). The length of roads with slope-along location exceeds $3 \mathrm{~km}(3033 \mathrm{~m})$, with the share of ideal slope-along roads (IARRR $=90$ deg) equals to $205 \mathrm{~m}$. The share of slopeperpendicular roads amounts to $1873 \mathrm{~m}$ with just $81 \mathrm{~m}$ of ideal slope-perpendicular location (IARRR $=0$ ). The detailed results are shown on Figure 1 and their spatial representation on Figure 2.

\section{UHRR indicator}

The results (Tab. 3) show very high share of road sections requiring urgent protection

TABLE 2. The location of rural roads in relief according to IARRR indicator for Mielnica watershed

\begin{tabular}{|c|l|r|r|}
\hline \multirow{2}{*}{ IARRR } & \multicolumn{2}{|c|}{ Road arrangement in relief } & \multicolumn{2}{|c|}{ Road length } \\
\cline { 3 - 4 } & & \multicolumn{1}{c|}{$\mathrm{m}$} & \multicolumn{1}{c|}{$\%$} \\
\hline 0 & Ideally perpendicular to slope & 81 & 0.4 \\
\hline $0-10$ & Perpendicular to slope & 1873 & 9.5 \\
\hline $11-80$ & Diagonal to slope & 14746 & 74.8 \\
\hline $81-90$ & Along to slope & 3033 & 15.6 \\
\hline 90 & Ideally along to slope & 205 & 1.0 \\
\hline Total & & 19702 & 100.0 \\
\hline
\end{tabular}




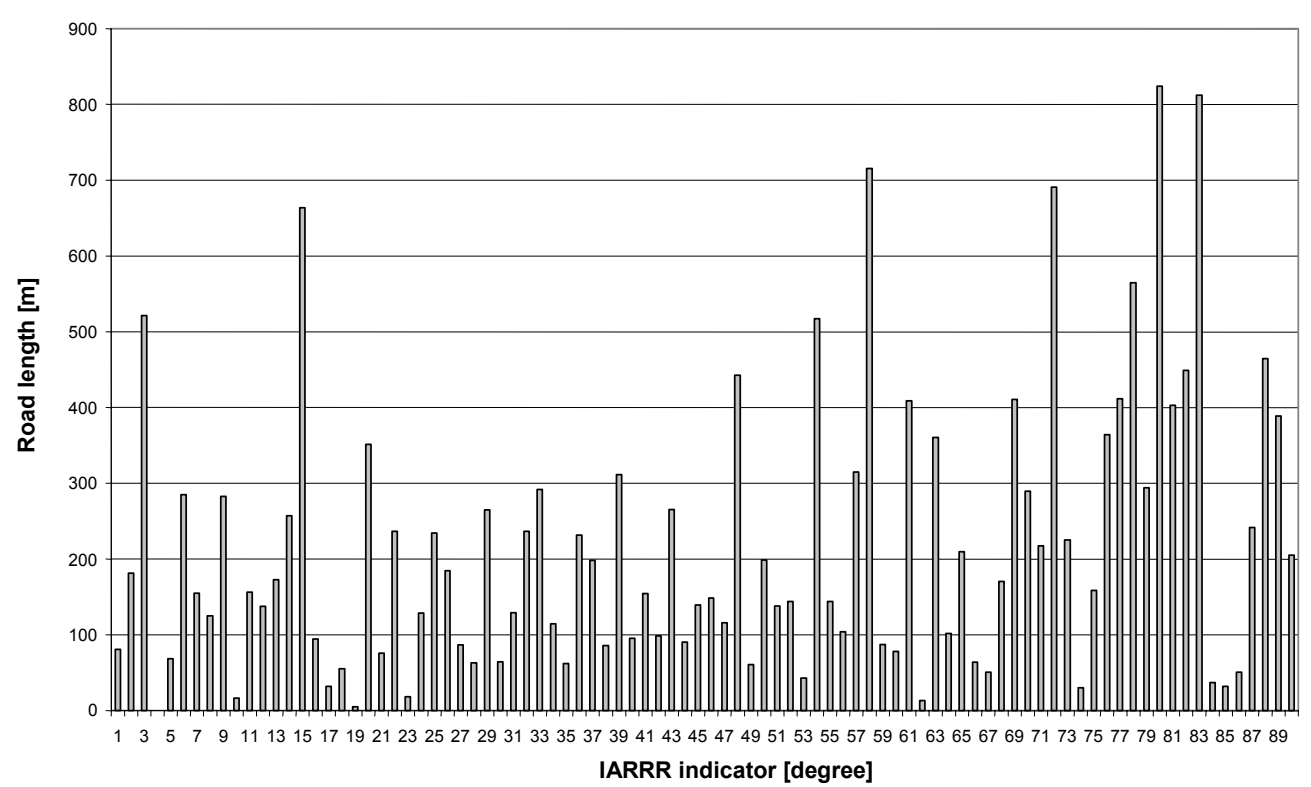

FIGURE 1. Histogram of IARRR indicator values for existing road network in the area of Mielnica watershed

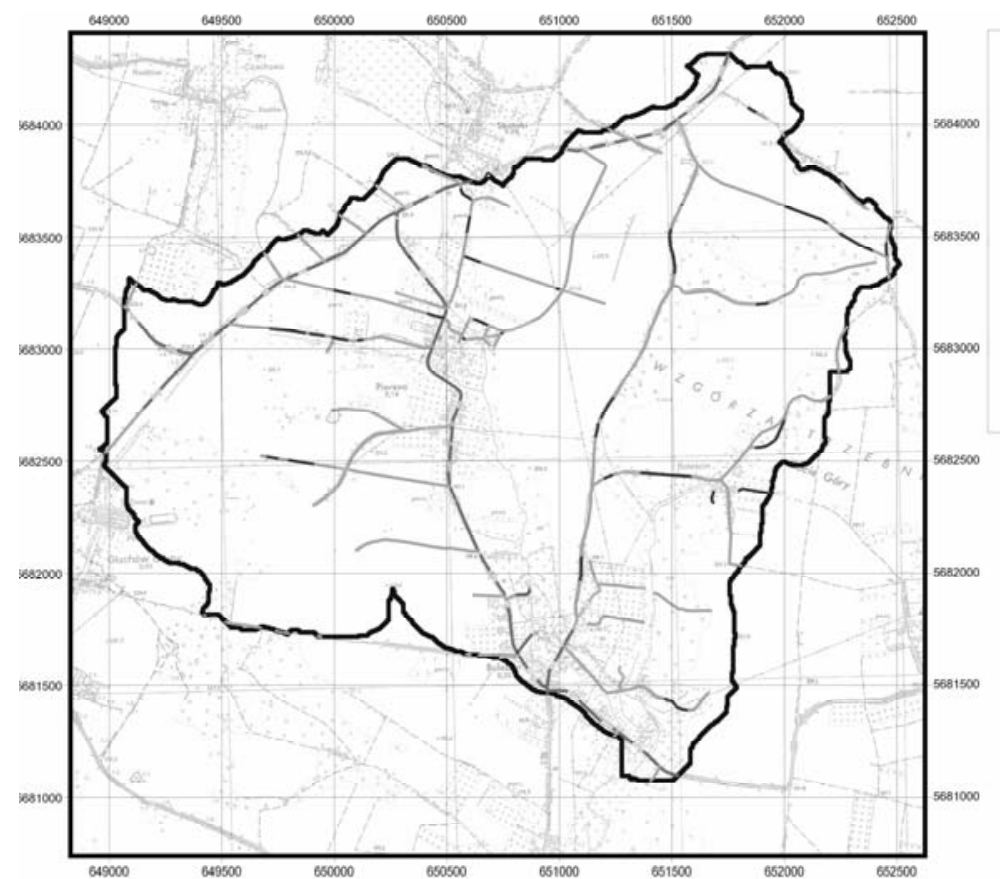

\section{LEGEND}

Rural roads - IARRR indicator

$-0$

$-0.10$

- $10 \cdot 80$

- $\quad 80-90$

$\longrightarrow 90$

- Public roads

$\square$ Watershed border

FIGURE 2. Map of IARR indicator in Mielnica watershed 
TABLE 3. The location of rural roads in relief according to IARRR indicator for Mielnica watershed

\begin{tabular}{|c|l|r|r|}
\hline \multirow{2}{*}{ UHRR } & \multirow{2}{*}{$\begin{array}{l}\text { Hardening of roads' surface and strengthening } \\
\text { of draining devices }\end{array}$} & \multicolumn{2}{|c|}{ Road length } \\
\cline { 3 - 4 } & & \multicolumn{1}{|c|}{$\mathrm{m}$} & \multicolumn{1}{c|}{$\%$} \\
\hline 1 & Very urgent & 2757.6 & 14.0 \\
\hline 2 & Urgent & 7033.8 & 35.7 \\
\hline 3 & Moderately urgent & 0.0 & 0.0 \\
\hline 4 & Advisable locally & 9910.1 & 50.3 \\
\hline Total & & 19702.0 & 100.0 \\
\hline
\end{tabular}

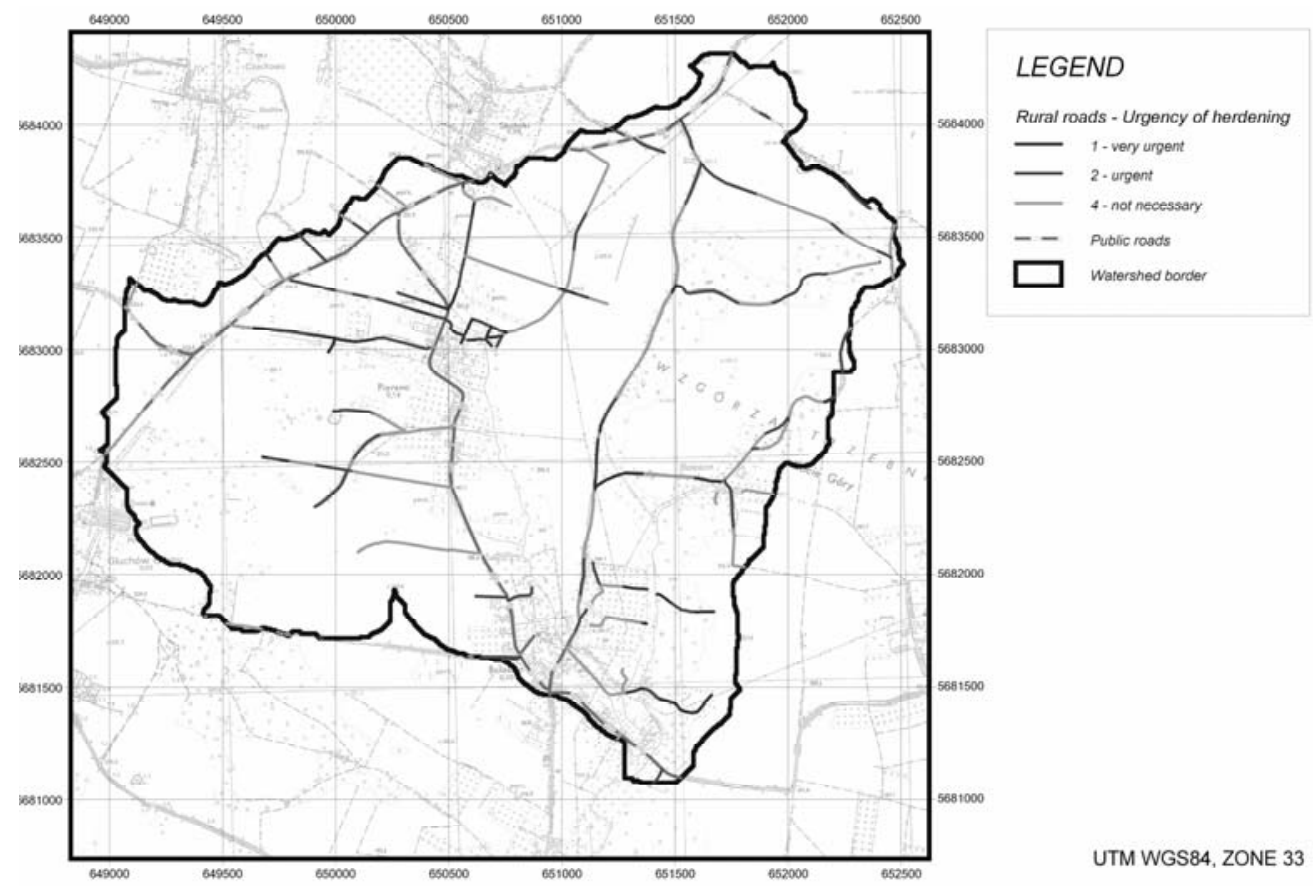

FIGURE 3. UHRR indicator values for existing network of agricultural roads within Mielnica watershed

measures in form of surface hardening and establishing infrastructure for draining superficial waters. Almost $50 \%$ of roads located within the watershed need urgent and very urgent measures. Basing on the UHRR indicator it is possible to spatially derive the most endangered road sections, which should be managed in the first place, which is shown on Figure 3.

\section{DISCUSSION}

The values of IARRR indicator characterizing the existing network of rural roads within the Mielnica watershed show rela- 
tively unfavorable arrangement of rural roads in terrain's relief, since the share of good (slope-perpendicular) allocated road sections presents only $15.6 \%$. In case of future land improvements and reparcelling projects, this structure should be rebuilt to liquidate slope-along road sections and diminish the share of slope-perpendicular ones $[10,11]$.

Comparing the results obtained in Mielnica watershed with the ones from former investigations on Grodarz watershed [15] on Lublin Upland, roads in Mielnica have a bit better IARRR values, since the share of slope-perpendicular roads is $2.2 \%$ higher. However the share of slope-along roads remains very similar. Both watersheds have similar characteristics of terrain relief with long steep slopes, gullies and a wide valley [6]. The high share of unfavorable arrangement of rural roads may be explained by the high slope gradients between plateaus and the bottom of the valley, on which there is a tendency to use the shortest - slope-along way.

The values of UHRR indicator show also incorrect actual state of the network of rural roads within the watershed. Almost $50 \%$ of road sections need urgent measures of surface hardening and establishing draining infrastructure. $14 \%$ of all road sections require immediate intervention. The same analysis, performed for the area of Grodarz watershed [14] revealed respectively $27 \%$ and $13 \%$.

\section{REFERENCES}

1. FOEHLICH W., SŁUPIK J., 1980: Land roads as a source of water and sediment income to watercourse. Zesz. Probl. Post. Nauk Rol., 225: 257-268.

2. GEIGER J., 2001: Line.FromandToAz script, version 2.5. Manual, p. 2.
3. HUTCHINSON M.F., 1989: A New Procedure for Gridding Elevation and Stream Line Data With Automatic Removal of Spurious Pits. Journal of Hydrology: 106, 211-232.

4. JENNESS J., Surface Tools for Points, Lines and Polygons (v. 1.2) Manual, p. 22 http://www. jennessent.com/arcview/surface_tools.htm

5. JÓZEFACIUK Cz., NOWOCIEŃ E., WAWER R., 2000: Sytuowanie dróg w terenach erodowanych [Locating Rural Roads on Eroded Terrains]. Folia Univesitatis Agriculturae Stetinensis. Z. 217 Agric. 87, p. 77-80 [in Polish].

6. JÓZEFACIUK Cz., JÓZEFACIUK A., NOWOCIEŃ E., WAWER R., 2002: Przeciwerozyjnezagospodarowaniezlewniwyżynnej potoku Grodarz z uwzględnieniem ograniczania powodzi [Anti-Erosion Management of Upland Watershed of Grodarz Stream, Considering Flood Mitigation]. MONOGRAFIE I ROZPRAWY NAUKOWE, Wyd. IUNG, z. 4, s. 69 [in Polish].

7. JÓZEFACIUK Cz., JÓZEFACIUK A., 1996: Erozja i melioracje przeciwerozyjne [Erosion and Anti-Erosion Meliorations]. Biblioteka Monitoringu Środowiska, Warszawa, s. 144 [in Polish].

8. JÓZEFACIUK Cz., JÓZEFACIUK A., 1999: Ochrona gruntów przed erozją. [Protection of Grounds Against Erosion]. Wydawnictwo IUNG, Puławy, s. 109 [in Polish].

9. NOWOCIEŃ E., 1996: Dynamika rozwoju wąwozów drogowych na obszarach lessowych [The Dynamics of Road-Gullies development on loess terrains]. Pam. Puł., z. 107, s. 101-111 [in Polish].

10. NOWOCIEŃ E., 1997: Specyfika planowania dróg rolniczych w terenach erodowanych [The Specifics of Rural Roads Planning on Eroded Terrains]. Zesz. Naukowe AR we Wrocławiu, z. 312, s. 209-216 [in Polish].

11. NOWOCIEŃ E., 1999: Badania nad planowaniem i projektowaniem wybranych elementów dróg rolniczych na wyżynnych obszarach chronionego krajobrazu [The Investigations on Planning and Projecting of Chosen Rural Roads' Elements on Upland Areas of Protected Landscape]. Pam. Puł., z. 119, s. 93-100 [in Polish].

12. NOWOCIEŃ E., 2003: The Study Of Planning And Designing Some Elements Of 
Agricultural Roads Located Within Upland Protected Areas. Electronic Journal of Polish Agricultural Universities, Volume 6, Issue 2, CIVIL ENGINEERING Series, http://www. ejpau.media.pl/series/volume6/issue2/civil/ art-03.html

13. STARKEL L., 1980: Erozja gleb a gospodarka wodna w Karpatach. Zesz. Probl. Post. Nauk Rol., 235: 103-118

14. WAWER R., 2003: Zastosowanie cyfrowego modelu zlewni potoku Grodarz dla celów zagospodarowania przeciwerozyjnego [The Application of Digital Modeling of Grodarz Stream Watershed for Anti-Erosion Management]. Dissertation, IUNG, s. 91 [in Polish].

15. WAWER R., 2004: An Indicator for Estimating Arrangement of Rural Roads in Terrains Relief and Its Digital Implementation in GIS on the Example of Grodarz Stream Watershed, Electornic Journal of Polish Agricultural Univeristies. Civil Engineering Series. Vol. 7, Issue 2.

16. ZIEMNICKI S., 1968. Melioracje przeciwerozyjne [Anti-Erosion Meliorations]. PWRiL, Warszawa, s. 360 [in Polish].

Streszczenie: Poprawa struktury przestrzennej i jakości sieci dróg rolniczych $w$ wyżynnej zlewni lessowej. Na terenach silnie erodowanych znaczna część dróg rolniczych, w szczególności tych o wadliwej lokalizacji w rzeźbie terenu, przekształca się w wąwozy. Dlatego też właściwa lokalizacja i utwardzanie nawierzchni dróg rolniczych są ważnym elementem kształtowania przestrzeni rolniczej. Właściwe wyznaczenie odcinków dróg, wymagających zabiegów ochronnych bądź w skrajnych przypadkach - przeprojektowania; pozwala na ekonomicznie efektywną poprawę stanu sieci dróg rolniczych, kierując środki na odcinki najbardziej zagrożone. Opracowanie przedstawia studium aktualnego stanu sieci dróg rolniczych na obszarze wyżynnej zlewni rolniczej potoku Mielnica, położonej na podatnych na erozję wodną glebach lessowych. Analizy przeprowadzone na przestrzennych danych cyfrowych w systemach GIS wykazały znaczna potrzebę wprowadzenia działań ochronnych. $\mathrm{Na}$ podstawie wyników analiz wyznaczono mapę odcinków dróg o różnej pilności ochrony, stanowią podstawę do przyszłych scaleń, decyzji administracyjnych i zarządzania siecią dróg rolniczych na badanym obszarze.

\section{MS. received April 2010}

Authors' addresses:

\section{Rafal Wawer, Eugeniusz Nowocień, Bugusław Podolski}

Institute of Soil Science and Plant Cultivation - State Research Institute

ul. Czartoryskich 8

24-100 Puławy

tel. 818863421

e-mail:huwer@iung.pulawy.pl

www.erozja.iung.pulawy.pl

Spatial Applications Division,

Katholieke Universiteit Leuven

Szymon Szewrański, Romuald Żmuda

Agricultural University of Wroclaw 